University of Rhode Island

DigitalCommons@URI

Open Access Master's Theses

1980

\title{
EFFECTS OF LIQUID MEMBRANES ON GASTROINTESTINAL ABSORPTION OF DRUGS IN RATS
}

Alan Paul Agins

University of Rhode Island

Follow this and additional works at: https://digitalcommons.uri.edu/theses

\section{Recommended Citation}

Agins, Alan Paul, "EFFECTS OF LIQUID MEMBRANES ON GASTROINTESTINAL ABSORPTION OF DRUGS IN RATS" (1980). Open Access Master's Theses. Paper 178.

https://digitalcommons.uri.edu/theses/178

This Thesis is brought to you for free and open access by DigitalCommons@URI. It has been accepted for inclusion in Open Access Master's Theses by an authorized administrator of DigitalCommons@URI. For more information, please contact digitalcommons-group@uri.edu. 


\author{
EFFECTS OF LIQUID MEMBRANES ON \\ GASTROINTESTINAL ABSORPTION \\ OF DRUGS IN RATS \\ BY \\ ALAN PAUL AGINS
}

A THESIS SUBMITTED IN PARTIAL FULFILLMENT OF THE

REQUIREMENTS FOR THE DEGREE OF

MASTER OF SCIENCE

IN

PHARMACOLOGY AND TOXICOLOGY

UNIVERSITY OF RHODE ISLAND

1980 


\section{MASTER OF SCIENCE THESIS \\ OF \\ ALAN PAUL AGINS}

Approved:

Thesis Committee

Major Professor

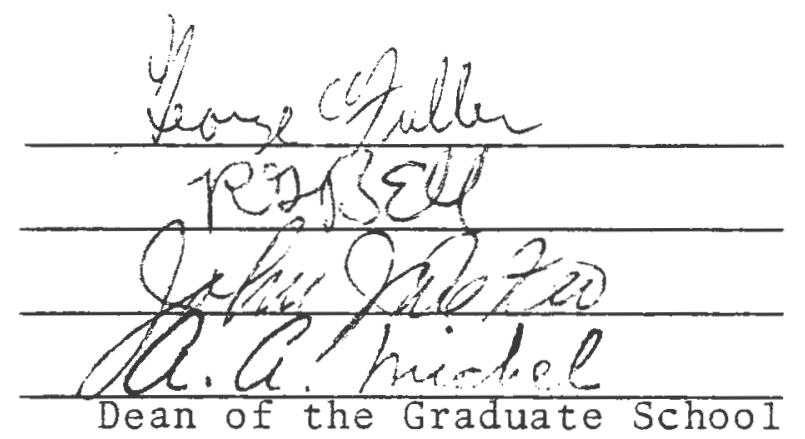

UNIVERSITY OF RHODE ISLAND 


\section{ABSTRACT}

Agins, Alan Paul. M.S., University of Rhode Island, 1980. Effects of Liquid Membranes on Gastrointestinal Absorption of Drugs in Rats. Major Professor: Dr. George C. Fuller.

A liquid membrane system was investigated as a potential antidotal treatment for acute drug overdose. The effectiveness of orally administered liquid membranes in simulated acute secobarbital, phencyclidine and strychnine poisoning was assessed in fasting rats.

Four mililiters of a liquid membrane suspension was administered immediately following drug intubations. The effect of liquid membrane on gastrointestinal absorption of secobarbital and phencyclidine was determined by comparison of duration of action (sleeping time) and blood drug concentration over time in drug controls and treated rats. The effect on phencyclidine absorption was also determined from the total amount of drug and metabolites excreted in the urine over twenty-four hours. The effectiveness of liquid membranes and activated charcoal for reducing strychnine absorption was assessed by acute toxicity experiments.

Duration of action of phencyclidine was 22 percent longer in liquid membrane treated rats while no significant difference existed between groups in secobarbital sleeping times. 
Blood level versus time analysis revealed no differences in blood levels between control and treated groups in both secobarbital and phencyclidine experiments. No difference existed in the total recovery of phencyclidine in urine in control and treated groups. Liquid membranes failed to protect rats from strychnine induced toxicity, whereas activated charcoal completely inhibited the toxic effect.

These studies show that liquid membranes are relatively ineffective in reducing drug absorption in vivo and that the system probably serves as a reservoir for sustained release of the drug as it passes through the gastrointestinal tract. The lack of in vivo efficacy may be attributed to an appreciable reduction in liquid membrane stability in the presence of gastrointestinal constituents such as bile salts and pancreatic secretions. 


\section{ACKNOWLEDGEMENTS}

The author wishes to express his sincere appreciation to Dr. George C. Fuller for his guidance and understanding during this investigation.

Thanks are also extended to the faculty and fellow graduate students of the Department of Pharmacology and Toxicology of the University of Rhode Island.

Special thanks are conveyed to Jeannee Yermakoff and William Lindblad for their moral and intellectual support over the years.

Finally, I would like to express my deepest thanks and appreciation to my wife, Paula, for her unending support, encouragement and sacrifice and my son, Daniel, for the joy he has brought to our lives. 


\section{DEDICATION}

To Paula 
TABLE OF CONTENTS

Page

ABSTRACT . . . . . . . . . . . . . . . . . . .

ACKNOWLEDGMENTS • • . . . . . . • • . . . . . . . • v

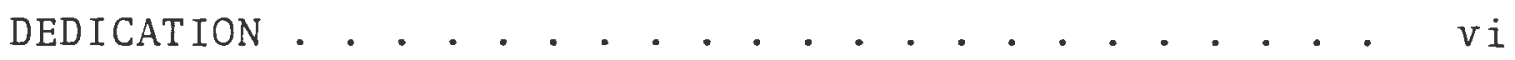

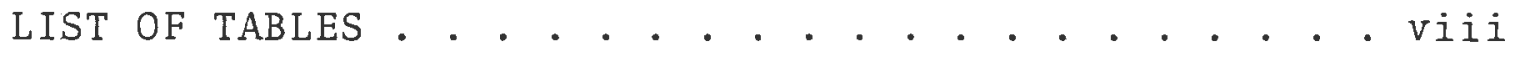

LIST OF FIGURES . . . . . . . . . . • . . . . . . . . ix

INTRODUCTION . . . . . . . . . . . . . . . . . . . . . . . . . 1

LITERATURE SURVEY • . . . . . . • . • • . . . . . 3

Antidotal Treatment . . . . . . . . . . . . . 3

Liquid Membranes . . . . . . . . . . . . . 7

EXPERIMENTAL • . • . . . . . . . • . . . . . . 13

Animals . . . . . . . . . . . . . . . . . . 13

Materials . . . . . . . . . . . . . . 13

Liquid Membrane Formulations . . . . . . . . . 14

Liquid Membrane Suspensions . . . . . . . . . 14

Procedures . . . . . . . . . . . . . . . . . . 15

Strychnine Acute Toxicity . . . . . . . . . . 15

Determination of Blood Secobarbital . . . . . . 16

Determination of Blood Phencyclidine . . . . . . 17

Recovery of Phencyclidine in Urine . . . . . . . 19

Statistical Methods... . . . . . . . . 20

RESULTS . . . . . . . . . . . . . . . . . . . 21

Sleeping Time Experiments . . . . . . . . . . 21

Blood Level Experiments . . . . . . . . . . . 23

Recovery of Phencyclidine in Urine . . . . . . . 30

Strychnine Acute Toxicity . . . . . . . . . . 34

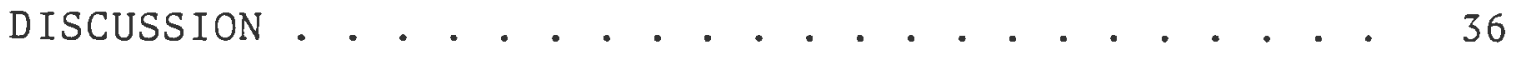

CONCLUSIONS . . . . . . . . . . . . . . . . . . . . 42

REFERENCES . . . . . . . . . . . . . . . . . . 43

APPENDIX . . . . . . . . . . . . . . . . . . . . . . 46

$\mathrm{VITA}$. . . . . . . . . . . . . . . . . . . . 50 


\section{LIST OF TABLES}

$\underline{\text { Table }}$

Page

I. Effect of Liquid Membrane Administration on Secobarbital Sleeping Time in Rats... . . . 22

II. Effect of Liquid Membrane Administration on Phencyclidine Sleeping Time in Rats . . . . . 24

III. Summary of the Effects of Liquid Membrane Administration on Secobarbital Bioavailability Parameters in Rats... . . . . . . . . 27

IV. Summary of the Effects of Liquid Membrane Administration on Phencyclidine Bioavailability Parameters in Rats... . . . . . . . . 31

V. Effect of Liquid Membrane Administration on Recovery of Phencyclidine in Rat Urine . . . . . 33

VI. Comparison of the Effectiveness of Liquid Membrane and Activated Charcoal Administration in Preventing Strychnine Toxicity in Rats . . 


\section{LIST OF FIGURES}

Figure

Page

I. Gas Chromatogram for the Analysis of Secobarbital Levels in Rat Blood . . . . . . . 25

II. Effect of Liquid Membrane Administration on Blood Levels of Secobarbital in Rats . . . . . 26

III. Gas Chromatogram for the Analysis of Phencyclidine Levels in Rat Blood . . . . . . 28

IV. Effect of Liquid Membrane Administration on Blood Levels of Phencyclidine in Rats . . . . 29

V. Gas Chromatogram for the Analysis of Phencyclidine and Metabolites in Rat Urine . . . . 32 


\section{INTRODUCT ION}

Human poisoning involving drug ingestion is common in the United States. Recent statistics show the number of accidental deaths from drugs increased by over 50 percent between 1968 and 1976 (National Clearinghouse, 1978). In addition, the number of non-fatal poisonings is estimated to exceed one million per year, or about one per 200 population (Goldstein et a1., 1974).

Traditionally, acute drug overdoses have been treated by a variety of methods including gastric lavage, emetics, adsorbants, forced diuresis, peritoneal or hemodialysis. Some of these methods have limited efficacy, require skilled manpower, can lead to further complications in the patient, and at the very least are extremely unpleasant.

Frankenfeld and coworkers (1976) first proposed the use of liquid membranes as an adsorbant system for antidotal treatment of acute drug overdose. They suggested that liquid membranes offer a number of potential advantages over many of the current methods including ease of preparation and administration, minimal patient resistance, and the ability to incorporate a variety of trapping agents would make them useful for a broad spectrum of drugs. 
Although liquid membrane technology is still at an early stage, preliminary in vitro data indicate potentially good efficacy and the need for evaluation of in vivo performance.

The present study represents the first attempt to evaluate liquid membrane performance in trapping drugs in the gastrointestinal tract of laboratory animals. 


\section{LITERATURE SURVEY}

\section{Antidotal Treatment}

Antidotal procedures are based on two concepts: first, the intensity of all chemical-biological reactions is related to the dose, or more accurately to the concentration of the chemical at the effector site in the tissue and second, following administration of a chemical to a biological speciman, the concentration of the chemical within the tissues is dependent upon the ability of biological barriers to prevent its translocation and on the chemical properties of the compound which permit or prevent its translocation in the tissue. In addition, since translocation is a time dependent process, it may be said that the intensity of all chemicalbiological reactions is time dependent (Loomis, 1978).

The present modes of emergency treatment in acute drug overdose are thus aimed at reducing the effective concentration of the drug at the site where the interaction occurs, thereby reducing the intensity and duration of the toxic effect. Within this framework, there exist both specific and non-specific procedures directed at either decreasing the rate or amount of drug absorption from the gastrointestinal tract, increasing the rate of elimination of the 
drug from the body, or increasing the threshold for toxicity by administration of a specific pharmacological antagonist. In the latter case, however, specific antidotes exist for relatively few drugs and therefore the major thrust of antidotal treatment lies in non-specific methodologies and must be tailored to the individual and the situation (Levine, 1978).

In the case of orally ingested compounds, removal of the unabsorbed chemical from the gastrointestinal tract represents the most direct and widely employed procedure for preventing further absorption of the drug. Abdallah and Tye (1967) studied the effectiveness of emetic drugs and stomach lavage in dogs fed a barium meal. Their results indicated that emesis was superior to lavage and that apomorphine was the most effective emetic agent. This study also showed that recovery of barium meal was dependent on the interval of time between ingestion and initiation of the procedure. In addition, with respect to apomorphine induced emesis, it was found that the action of this agent was completely inhibited in animals treated with hypnotic doses of thiopental. The authors concluded that following ingestion of overdoses of sedative type drugs, the production of emesis by centrally acting emetic agents cannot be relied on. Furthermore, apomorphine induced emesis can be quite severe and potentiate CNS depressant effects of sedative drugs (Arena, 1974). Syrup of Ipecac is generally considered a safer agent for the induction of emesis since it has a 
direct action on the gastric mucosa and can be eliminated with the vomitus. The effectiveness of the agent, however, tends to be quite variable and often requires fifteen to thirty minutes before onset of action (Lawson and Proudfoot, $1971)$

Gastric aspiration and lavage is a procedure that is controversial among physicians. Those who advocate use of the procedure contend that although the amount of drug recovered by this means is extremely variable, in some cases substantial amounts can be recovered with benefit to the patient (Matthew et a1., 1966). Others contend that the lavage procedure, if improperly performed, can lead to aspiration of lavage fluids, hasten gastric emptying into the intestine and in some cases, such as strychnine poisoning, the stimulation associated with intubation may precipitate convulsions (Meyers et a1., 1976).

Once actual removal of an ingested drug has been attempted or accomplished the use of adsorbants for further decontamination may be indicated. Activated charcoal has been advocated as an effective therapeutic agent in acute ingestions for many years (Holt and Holtz, 1963). In vitro studies (Decker et a1., 1968) have shown that this agent is capable of adsorbing a wide variety of toxic materials from aqueous solutions, although there is considerable variability in amounts depending on the material. Gosselin and Smith (1966) have emphasized that adsorption is not the same as chemical destruction and that adsorption may be reversible, 
leading to release of the offending chemical as the $\mathrm{pH}$ of the environment changes during passage through the gastrointestinal tract. Some in vivo studies, however, have shown activated charcoal to be effective. Fiser et al. (1971) reported that in dogs receiving barbiturates and glutethimide, administration of activated charcoal one-half hour after drug intubation resulted in significantly decreased serum levels of the compounds and a concommitant reduction in CNS depression. In addition, the charcoal-drug complex appeared to be stable, in that no significant dissociation was demonstrated over the twenty-four hour monitored experiments. Levy and Tsuchiya (1972) found that activated charcoal was effective in reducing aspirin absorption in man. They reported, however, that the adsorption on activated charcoal was partially reversible and was probably due to the higher $\mathrm{pH}$ of intestinal fluids and the competitive effects of constituents of these fluids. Despite the increasingly frequent recommendations in the literature that activated charcoal be used as a gastrointestinal decontaminant, the substance is rarely employed due to the lack of demonstrated efficacy in life-threatening acute intoxications under controlled conditions (Hayden and Comstock, 1975).

A variety of other adsorbants including cholestyramine (Dordoni et al., 1973), Arizona montmorillonite and evaporated milk (Chin et a1., 1969) and "universal antidote" (Picchioni et a1., 1966) have been evaluated as alternatives to activated charcoal. Although these substances may be useful in 
isolated cases, none appear to have the general applicability of activated charcoal. In the case of "universal antidote," it has been demonstrated that the combination of tannic acid and magnesium oxide with activated charcoal interfers with the adsorbant activity of the charcoal and is hence less effective than activated charcoal alone (Picchioni et al., 1966).

Cathartics such as liquid petrolatum, sodium sulfate, and magnesium hydroxide have also been implicated for preventing absorption and hastening the transit of chemical through the intestine. However, information on the effectiveness of such procedures is lacking (Loomis, 1978).

\section{$\underline{\text { Liquid Membranes }}$}

Liquid membranes were developed at Exxon Corporation (Li, 1968) as an industrial encapsulation process to solve a variety of separation problems. Since then, liquid membranes have been implicated for several industrial applications including separation of hydrocarbons and the removal of organic contaminants such as phenol (Cahn and Li, 1974)

and toxic inorganic ion such as $\mathrm{Cr}^{6+}, \mathrm{Hg}^{2+}$, and $\mathrm{Cd}^{2+}$ (Kitagawa et al., 1977) from wastewater.

Liquid membranes are thin, spherical liquid shells which encapsulate microscopic droplets of one phase and separate these from a bulk external phase. Liquid membranes are formed by first making an emulsion of two immiscible phases and then dispersing the emulsion in a third phase (continuous 
phase). The continuous phase and the encapsulated phase are generally miscible, but they are not miscible with the membrane phase. There are presently three types of liquid membrane systems (Appendix Table A). One is a water-in-oil-inwater emulsion, one is an oil-in-water-in-oil emulsion and the third is a gas-in-fluorocarbon-in-water system. The liquid membrane phase usually contains surfactants, additives, and a base material which is a solvent for the other ingredients. The surfactants and additives are used to control the stability, permeability, and selectivity of the membrane. The encapsulated phase can be formed into a "sink" for trapping certain agents, or as a reservoir for releasing substances into the external phase.

In recent years, interest has been focused on the potential application of liquid membranes in the biomedical and biochemical fields. A number of areas of research have been implicated including the encapsulation of enzyme processes, the sustained, slow release of compounds, oxygenation of blood, and removal of toxic substances from the human body. In the encapsulation of enzymes, liquid membranes may act to immobilize or protect enzymes from deactivating substances and non-optimal environments while maintaining free access to the desired substrate. In addition, preparations may allow for the encapsulation of necessary cofactors and optimal reaction conditions. May and Li (1974) encapsulated purified phenolase and dispersed the liquid membrane in an external aqueous phase containing phenol. Their results 
showed that phenol successfully diffused through the membrane, contacted the enzyme and was converted to oxidation products which accumulated in the internal phase. Another facet to enzyme encapsulation involves the delivery of specific enzymes to the intestinal tract. The liquid membranes would serve both to protect the enzyme from gastric degradation and as a reservoir for sustained release under physiological conditions.

Liquid membrane technology has also been extended to the area of blood oxygenatin. Conventional oxygenator devices, although efficient, eventually lead to damage of blood proteins and cells. Wallace et al., 1975) have found that oxygen encapsulated by certain fluorocarbons forms the basis for an excellent oxygenation device which circumvents many of these difficulties. They suggest that fluorocarbons are particularly suited for 1 iquid membrane material due to the high solubility of oxygen and carbon dioxide and the good compatability with blood. Experiments, in vitro and in dogs, have shown that the system is capable of replenishing oxygen and removing carbon dioxide from blood with no indication of damage to cells or other constituents.

The removal of toxic substances from the human body represents an interesting potential for liquid membranes. Research has been divided into two areas: the treatment of chronic uremia and the emergency treatment of acute drug overdose. 
Asher and coworkers $(1974,1976,1977,1978)$ have been developing a liquid membrane system that would serve as adjunct treatment to dialysis in chronic uremia. The system involves the use of two liquid membrane formulations for the removal of one of the uremic toxins, urea. In principle, urea diffuses from the blood into the intestine and is hydrolyzed into ammonia and carbon dioxide by the enzyme urease present in the intestinal lumen. In the presence of one of the liquid membrane formulations, containing an encapsulated organic acid, the lipid soluble ammonia species permeates the oil phase of the membrane, reacts with the encapsulated acid and becomes trapped in the form of an oil-insoluble ammonium ion. In addition, a liquid membrane formulation containing the enzyme urease would be given simultaneously. Since the levels of urease in the intestine are governed by the level of proteolytic activity of pancreatic secretions, the hydrolysis of urea may become rate limiting. Asher et al. (1977) have demonstrated a controlled release of the encapsulated phase of liquid membranes moderated by the levels of bile and pancreatin. They predicted that a higher concentration of pancreatic secretions, resulting in an increased rate of urease inactivation, would be balanced by a greater rate of release of the encapsulated enzyme to maintain activity in the small intestine. The instability of liquid membranes under physiological conditions, while advantageous in some circumstances, represents a problem with respect to those liquid membranes designed to trap toxins. To date, in vitro 
studies have been utilized primarily to identify proper formulations and suspending techniques necessary for obtaining biological stability. In addition, liquid membranes have been administered via cannulae to the small intestine of surgically azotemic dogs (Asher et al., 1979). Results indicate good mucosal tolerance to liquid membranes and substantial reduction of urea as measured by decreases in BUN levels.

The application of Iiquid membrane technology to acute drug overdose was first proposed by Frankenfeld and coworkers (1976). The principle involved in drug transport in liquid membranes is demonstrated in Appendix Figure A. The example is for an acidic drug such as secobarbital and a liquid membrane containing a basic pH buffer as the encapsulated phase. Drug transfer from the external aqueous phase follows the same principle governing passive diffusion of drugs through biological membranes, The unionized drug, having appreciable oil solubility, permeates the liquid membrane, diffuses in the direction of the concentration gradient and becomes ionized at the high $\mathrm{pH}$ of the central aqueous phase. A membrane made from hydrocarbon oil is virtually impenetrable to ions due to its low dielectric constant and hence the drug is trapped in the form of an oil-insoluble anion. The opposite situation would exist for basic compounds such as phencyclidine or the alkaloid, strychnine. The internal phase would consist of an acidic pH buffer and the drug would be trapped in the form of an oil-insoluble cation. 
In addition to ion-trapping, the internal aqueous phase can be formulated into a high capacity sink using plasma proteins, activated charcoal, or specific drug antibodies that bind tenaciously to drug.

In principle, ingested liquid membranes would pass through the gastrointestinal tract, trap and unabsorbed drug present in the lumen and be eliminated via the bowel.

The effectiveness of liquid membranes has been studied in vitro. Frankenfeld and coworkers (1976) have shown that under the most favorable conditions, liquid membranes are capable of rapid uptake of model drugs. Up to 95 percent of both phenobarbital and aspirin can be removed from donor solutions in five minutes or less of contacting time. Chaing et al. (1978) extended these studies to a number of other barbiturates. All the barbiturates, with the exception of barbital, were extracted more rapidly than phenobarbital (Appendix Table B). Most recently, Chilamkurti (1979) and Yang (1979) have studied the sophisticated kinetics involved in transfer of drug through liquid membranes. These studies, in addition to delineating the basic mechanisms governing solute transport, have identified some of the critical factors imparting efficacy to the system such as the diameter of the internal microdroplets, the viscosity of the oil phase, the strength of the encapsulated pH buffer, and chemical properties of the drug. 


\title{
EXPERIMENTAL
}

\begin{abstract}
Anima1s
Male Sprague-Dawley rats, weighing 250-300 grams, were purchased from Charles River Breeding Laboratories, Inc. (Wilmington, MA). The rats were housed in groups of six in colony cages at an ambient temperature of $24-27^{\circ} \mathrm{C}$ with alternating twelve hour 1 ight/dark cycles. Rats were fed Purina Laboratory Chow and water ad libitium. Rats were fasted twenty-four hours prior to experiments.
\end{abstract}

\section{Materials}

Secobarbital and Seconal sodium were obtained from Eli Lilly \& Company (Indianapolis, IN). Hexobarbital was obtained from $K$ \& $K$ Laboratories, Inc. (Plainview, NY). Strychnine sulfate was obtained from Mallinckrodt Chemical Works (St. Louis, MO). Ketamine hydrochloride (Ketaset ${ }^{\mathrm{R}}$ ) was obtained from Bristol Laboratories (Syracuse, NY). Activated charcoal was obtained from Sigma Chemical Company (St. Louis, MO). Phencyclidine hydrochloride was kindly donated by Dr. Robert E. Willette, National Institute of Drug Abuse, Rockville, MD. All other reagents used were anlaytical grade. 


\section{Liquid Membrane Formulations}

Liquid membrane forming emulsions, Codes 573-31(R) and 573-118-2 were supplied by Exxon Research and Engineering Company, Linden, NJ. The oil phase of both is composed of a combination of an isoparaffinic mineral oil (Isopar $\mathrm{M}^{\mathrm{R}}$ ) and a white mineral oil (Markol $87^{\mathrm{R}}$ ). A high molecular weight polyamine is present in the oil phase as a strengthening agent. The internal aqueous phase of $573-31(R)$ is a $\mathrm{pH} 10$ buffer consisting of boric acid, $\mathrm{KCl}$ and $\mathrm{NaOH}$. The internal aqueous phase of 573-118-2 is a pH 2 buffer made of $\mathrm{HCl}$ and $\mathrm{KCl}$. The ratio of oil phase to aqueous phase is $1: 1$ (Frankenfeld, 1979).

\section{Liquid Membrane Suspensions}

To a $250 \mathrm{ml}$ beaker are added $50 \mathrm{mls}$ distilled water, $0.5 \mathrm{~g}$ methylcellulose (4000cps), $0.2 \mathrm{~g} \mathrm{NaHCO}_{3}$, and $0.25 \mathrm{~g}$ $\mathrm{NaCl}$. The contents are mixed at approximate1y 1200 RPM for 1 minute using a variable speed mixer fitted with a one and one-half inch propeller. The mixing is reduced to approximately 400 RPM and $50 \mathrm{mls}$ of the liquid membrane forming emulsion is added. After 30 seconds, the mixing is reduced to approximately $100 \mathrm{RPM}$ and maintained for the duration of the experiment. Aliquots for intubation are drawn from the beaker with a $5 \mathrm{~m} 1$ plastic syringe fitted with a 16 gauge oral intubation tube. 


\section{Procedures}

Groups of rats received either secobarbital or phencyclidine by oral intubation. Drug solutions were made in water such that $0.1 \mathrm{~m} 1$ was administered per $100 \mathrm{~g}$ of body weight. Half the rats in each experiment received $4 \mathrm{~m} 1 \mathrm{~s}$ of the appropriate liquid membrane suspension, while the remaining rats received $4 \mathrm{mls}$ of water immediately after drug intubation.

In sleeping time experiments, time of drug intubation $\left(\mathrm{T}_{0}\right)$ was recorded for each animal. The time from drug intubation to the loss of righting response was recorded as latency $\left(T_{L}\right)$. At the onset of anesthesia, all animals were placed on their right sides. Sleeping time was measured as the duration of time from loss of righting response until the animal regained this response $\left(\mathrm{T}_{\mathrm{F}}-\mathrm{T}_{\mathrm{L}}\right)$.

In blood level experiments, blood samples (approx. 0.5 mls) were drawn from each rat by cardiac puncture at $30 \mathrm{~min}$, 1,2 , and 3 hours post intubation. Blood samples were immediately transferred to glass test tubes containing $0.02 \mathrm{~m} 1 \mathrm{~s}$ of a $3.75 \%$ EDTA solution as anticoagulant. Tubes were kept on ice until all samples had been collected.

\section{Strychnine Acute Toxicity}

Rats were divided into three groups. Each group received a dose of strychnine approximately one and one-half times the oral $\mathrm{LD}_{50}$ (Barnes and Eltherington, 1965). Immediately following drug intubation, one group received $4 \mathrm{mls}$ 
of a $35 \mathrm{mg} / \mathrm{ml}$ solution of activated charcoal in water. Time of drug intubation was recorded and all animals were maintained in an environment of minimal external stimuli. The number of deaths and the latency to death were recorded. Non-lethals were monitored for twenty-four hours post intubation.

\section{Determination of Blood Secobarbital}

Quantitation of secobarbital in the blood is determined gas chromatographically. Extraction of drug from blood is based on the procedure of Dvorchik (1975). Two hundred microliters of whole blood are placed in a glass test tube. Twenty microliters of a $300 \mu \mathrm{g} / \mathrm{ml}$ hexobarbital in acetone solution is added to each tube as an internal standard. Two mls of chloroform is then added and the tubes are vortexed for one minute followed by centrifugation at 500 RPM for five minutes. The chloroform phase is removed and transferred to clean $15 \mathrm{ml}$ conical centrifuge tubes. The chloroform is evaporated to dryness at room temperature under nitrogen. The walls of the tubes are then rinsed with $50 \mu 1$ chloroform and again evaporated to dryness. Secobarbital standards, ranging from 10 to $50 \mu \mathrm{g} / \mathrm{ml}$ are prepared by adding a known volume of a secobarbital in acetone solution to glass tubes and evaporating to dryness under a stream of nitrogen. Two hundred microliters of fresh blood is added to each tube and the contents mixed by gentle shaking. Standards are then extracted along with the blood samples as above. 
Prior to analysis, the tubes containing drug residue are reconstituted with $25 \mu 1$ of chloroform. Approximately $2 \mu 1$ of the chloroform extract are injected into a Packard mode1 804 gas chromatograph equipped with a flame-ionization detector. The column is a 3 foot $\mathrm{X} 1 / 8$ inch diameter glass column containing 3\% OV-1 on Gas Chrom Q 100/120. The column is preconditioned for 24 hours at $220^{\circ} \mathrm{C}$ and a nitrogen flow rate of about $15 \mathrm{ml} / \mathrm{min}$. The operating conditions are: injection port and detector $-250^{\circ} \mathrm{C}$, oven- $-190^{\circ} \mathrm{C}$, air flow rate- $300 \mathrm{ml} / \mathrm{min}$, hydrogen flow $\mathrm{rate}--30 \mathrm{~m} 1 / \mathrm{min}$ and nitrogen flow rate--35 $\mathrm{ml} / \mathrm{min}$. Sensitivity is set at $10^{-11}$, with an attenuation of 64 .

Quantitation is accomplished by obtaining a ratio of secobarbital peak height to hexobarbital peak height and comparing values to those obtained from the secobarbital standards.

\section{Determination of Blood Phencyclidine}

Quantitation of phencyclidine in blood specimens is based on the gas-chromatographic procedure of Reynolds (1976). The extraction procedure, using n-butyl chloride, is modified for smaller blood samples by ratioing extraction components. To glass test tubes is added $0.5 \mathrm{~m} 1 \mathrm{~s}$ of whole blood. Fifty microliters of a $100 \mu \mathrm{g} / \mathrm{ml}$ aqueous ketamine HCl solution are added to each tube as an internal standard. The contents are mixed briefly and are then made alkaline with two drops of $50 \% \mathrm{NH}_{4} \mathrm{OH}$. Two mls of n-butyl chloride 
are added and the tubes are vortexed for 2 minutes, then centrifuged at 500 RPM for 5 minutes. The top, or n-butyl chloride layer, is pipetted into a clean test tube and back extracted with $1.0 \mathrm{ml}$ of $0.5 \mathrm{~N} \mathrm{HCl}$ for 1 minute by vortexing. The layers are again separated by centrifugation and the $n$-butyl chloride layer is pipetted off and discarded. The HC1 layer is aerated for 2 minutes to remove al1 residual n-butyl chloride. The $\mathrm{HCl}$ is made strongly alkaline with 2 drops of $10 \mathrm{~N} \mathrm{NaOH}$ and reextracted with $1.0 \mathrm{ml}$ of chloroform for 1 minute. The chloroform layer is transferred to clean $5 \mathrm{ml}$ screw cap vials and evaporated to dryness at room temperature under nitrogen.

A series of standards ranging from 2.5 to $20 \mu \mathrm{g} / \mathrm{m} 1$ are prepared in drug free blood by the addition of known volumes of an aqueous phencyclidine solution. Standards are extracted along with the blood samples as described above.

The vials containing drug residue are reconstituted with $20 \mu 1$ of chloroform and approximately $2 \mu 1$ are injected onto the OV-1 column as described previously. The operating parameters are as follows: injection port-- $200^{\circ} \mathrm{C}$, oven-$180^{\circ} \mathrm{C}$, detector $-225^{\circ} \mathrm{C}$, air flow rate--300 $\mathrm{ml} / \mathrm{min}$, hydrogen flow $\mathrm{rate}--30 \mathrm{ml} / \mathrm{min}$ and nitrogen flow rate- $-40 \mathrm{ml} / \mathrm{min}$. Sensitivity is set at $10^{-11}$ with attenuation 32 . Quantitation is accomplished by comparison of peak height ratios of phencyclidine to ketamine in the unknown samples and the standards. 


\section{Recovery of Phencyclidine in Urine}

Groups of rats received either phencyclidine and water or phencyclidine and liquid membrane suspension. Immediately following intubations animals were placed in separate metabolic cages. Urine was collected over a 24 hour period after which urine volumes were recorded and samples analyzed for drug content.

Quantitation of unchanged phencyclidine and metabolites in urine is determined as follows: $2.0 \mathrm{~m} 1 \mathrm{~s}$ of urine are pipetted into $15 \mathrm{ml}$ round bottom screw-cap test tubes and subjected to mild hydrolysis by the addition of $0.3 \mathrm{mls}$ of $6 \mathrm{~N} \mathrm{HCl}$ and incubation in a $60^{\circ} \mathrm{C}$ water bath with gentle agitation for 30 minutes. When hydrolysis is completed, tubes are allowed to reach room temperature and then urine is made alkaline by addition of concentrated $\mathrm{NH}_{4} \mathrm{OH}$. To each tube are added $50 \mu 1$ of a $2 \mathrm{mg} / \mathrm{ml}$ aqueous ketamine solution as internal standard and $8.0 \mathrm{mls}$ of chloroform. The tubes are placed on a platform shaker, extracted for 10 minutes and then centrifuged at 500 RPM for 5 minutes. The urine is removed and discarded. The chloroform layer is filtered through whatman no. 541 filter paper containing sodium sulfate into $15 \mathrm{ml}$ screw-cap vials and evaporated to dryness at room temperature under nitrogen. Standards ranging from 50 to $200 \mu \mathrm{g} / \mathrm{ml}$ are prepared in drug free urine and extracted as above.

The drug residue is reconstituted with $50 \mu 1$ of chloroform and between 1 and $2 \mu 1$ are injected onto the OV-1 
column. All operating parameters are the same as described in the phencyclidine blood level determination section. Sensitivity was $10^{-10}$ with attenuation 32 . Quantitation of unchanged phencyclidine was accomplished using the method of peak height ratios as before, while quantitation of metabolites was accomplished by ratioing peak areas of metabolites to peak area of ketamine.

\section{Statistical Methods}

Students' t-test was used to test for significant differences between sample means. The sample means, standard errors of the means and t-statistics were calculated on an Olivetti-Underwood Programma 101 computer using the following formulae.

a) Arithmetic means of sample:

$$
\overline{\mathrm{X}}_{1}=\frac{\Sigma \mathrm{X}_{1}}{\mathrm{~N}_{1}} ; \overline{\mathrm{X}}_{2}=\frac{\Sigma \mathrm{X}_{2}}{\mathrm{~N}_{2}}
$$

b) Estimated standard error of the mean:

$$
\hat{\sigma}_{\bar{x}_{1}}=\frac{S_{1}}{\sqrt{N_{1}-1}} ; \hat{\sigma}_{\bar{x}_{2}}=\frac{S_{2}}{\sqrt{N_{2}^{-1}}}
$$

c) t-statistic:

$$
t=\frac{\bar{x}_{1}-\bar{X}_{2}}{\hat{\sigma}}
$$

Acceptable level of significance in these studies was defined as $p<0.05$ for a two-tailed t-test. 


\section{RESULTS}

Administration of four milliliters of liquid membrane suspension to control rats resulted in no overt effects and demonstrated that the animals could easily tolerate the volume of material. Rats remained normal and active. Stools from treated animals were greasy and soft and coated with a milky white, oily film.

\section{Sleeping Time Experiments}

Secobarbital at a dose of $100 \mathrm{mg} / \mathrm{kg}$, produced anesthesia in all rats in both drug control and liquid membrane treated groups. The mean latency to loss of righting response was the same in both groups. Mean sleeping time did not differ significantly between the two groups, however, the liquid membrane treated group showed approximately three times the variability of drug control (Table I).

Phencyclidine, at a dose of $50 \mathrm{mg} / \mathrm{kg}$, produced extreme ataxia and stereotypic behavior in al1 rats within five minutes after intubation. The latency to loss of righting response was not significantly different between drug control and liquid membrane treated groups. Al1 rats in both groups displayed mild clonus intermittently throughout the 
TABLE I

Effect of Liquid Membrane Administration on Secobarbital Sleeping Time in Ratsa

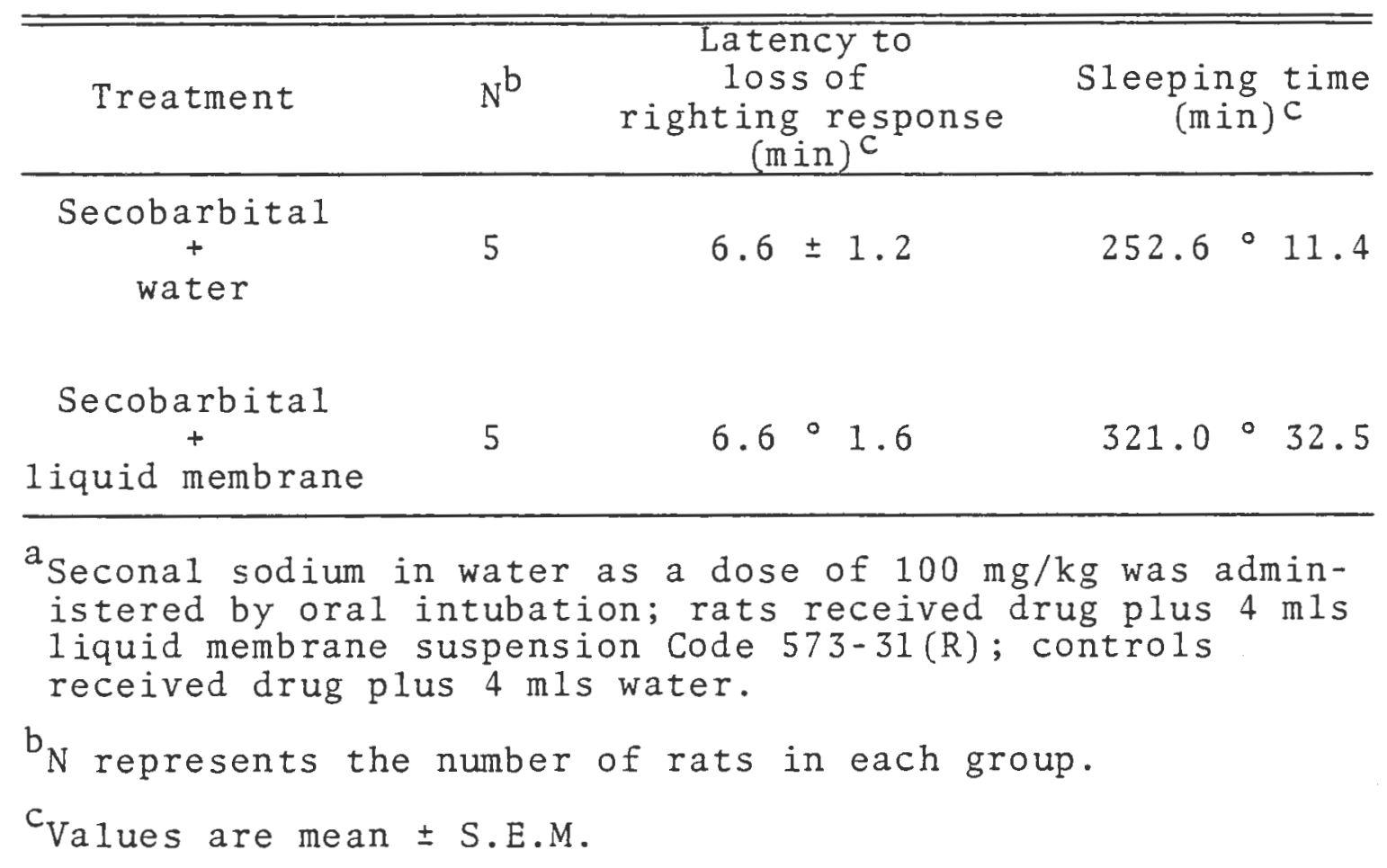


experiment. Mean sleeping time was $22 \%$ longer $(p<0.05)$ in the liquid membrane treated group (Table II).

\section{Blood Leve1 Experiments}

Under the GLC conditions described earlier, the secobarbital peak appears at 1.3 minutes and the hexobarbital internal standard peak at 1.7 minutes from the time of injection. An example of a chromatogram is shown in Figure I. The standard curve was linear throughout the range of concentrations tested.

The peak blood concentration of secobarbital for both the drug control and liquid membrane treated groups was observed at 30 minutes post intubation and levels declined over the next 2-1/2 hours (Figure II). There were no significant differences in mean blood levels between the two groups at all times analyzed. Analysis of area under the blood concentration versus time curves showed that bioavailability of drug was within $3 \%$ for the two groups (Table III).

An example of a chromatogram for phencyclidine analysis is shown in Figure III. Under the described GLC conditions, the Ketamine internal standard peak appears at 2.0 minutes and the phencyclidine peak at 2.5 minutes after injection. The standard curve was Iinear throughout the range of concentrations tested and passed through the origin. Figure IV shows the blood concentration versus time curve for drug control and liquid membrane treated groups. Blood levels 
TABLE I I

Effect of Liquid Membrane Administration on Phencyclidine Sleeping Time in Rats ${ }^{a}$

\begin{tabular}{|c|c|c|c|}
\hline Treatment & $N^{b}$ & $\begin{array}{c}\text { Latency to } \\
\text { loss of } \\
\text { righting resonse } \\
\text { (min)c }\end{array}$ & $\underset{(\text { min })}{\text { Sleeping time }}$ \\
\hline $\begin{array}{c}\text { Phencyclidine } \\
+ \\
\text { water }\end{array}$ & 5 & $12.6 \pm 1.8$ & $108.2 \pm 6.4$ \\
\hline $\begin{array}{c}\text { Phencyclidine } \\
+ \\
\text { liquid membrane }\end{array}$ & 5 & $11.0 \pm 1.0$ & $139.4 \pm 10.3^{d}$ \\
\hline \multicolumn{4}{|c|}{ 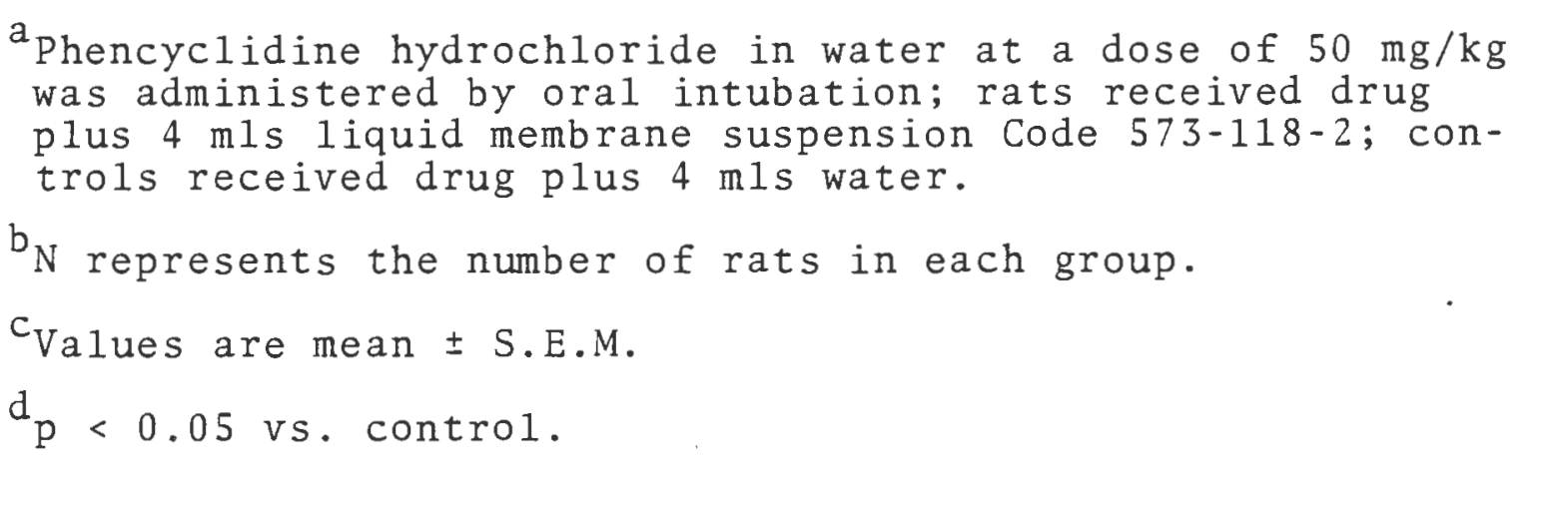 } \\
\hline
\end{tabular}




\section{FIGURE I}

Gas Chromatogram for the Analysis of Secobarbital Levels in Rat Blood ${ }^{a, b}$

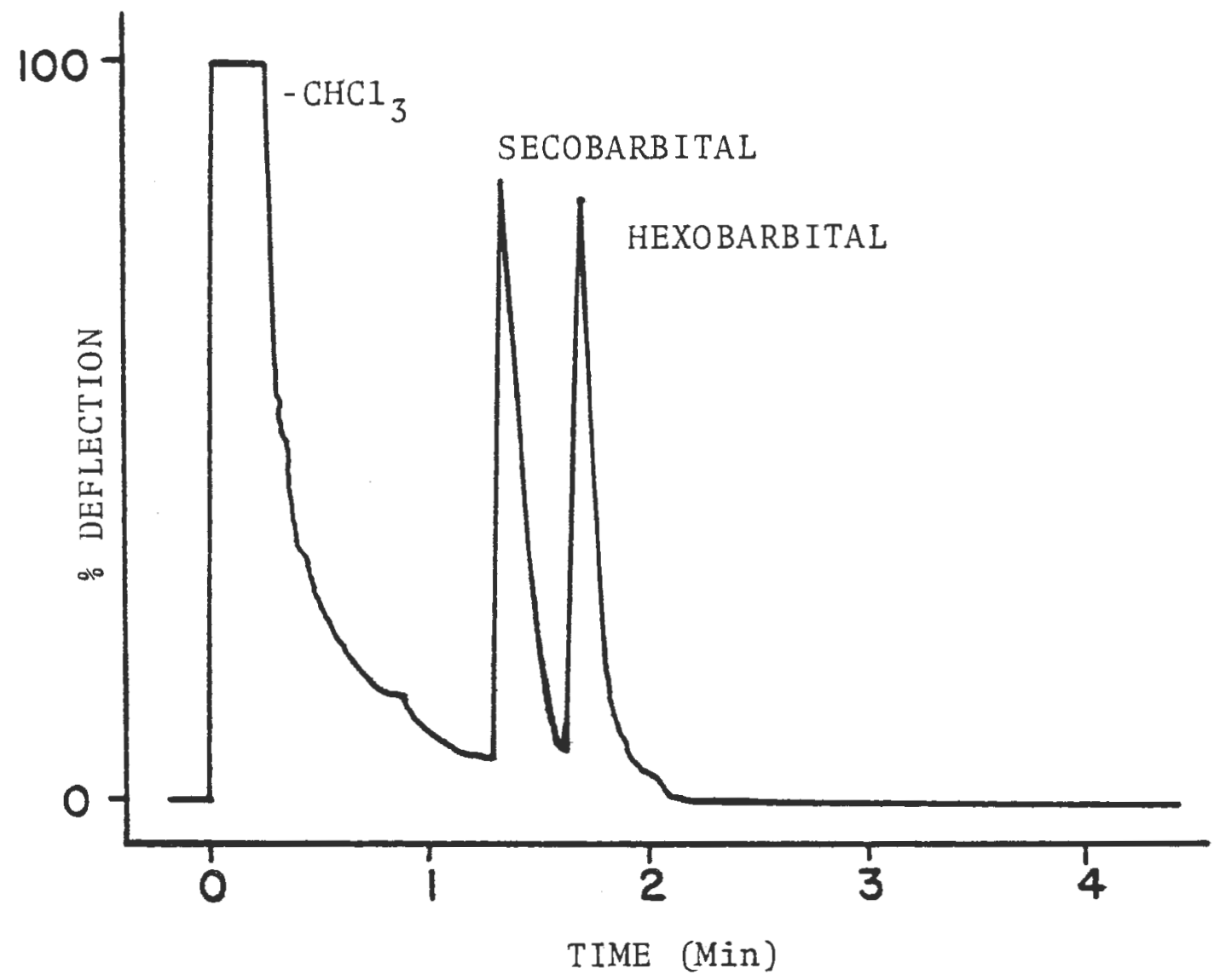

abtained from the injection of two microliters of a chloroform extract from $0.2 \mathrm{mls}$ whole blood.

${ }^{\mathrm{b}}$ Column was a $3^{\prime} \mathrm{X} 1 / 8$ " glass column containing $3 \%$ OV -1 on Gas Chrom Q 100/120; Oven temperature-190". 


\section{FIGURE I I}

Effeet of Liquid Membrane Administration on Blood Levels of Secobarbital in Rats ${ }^{a}$

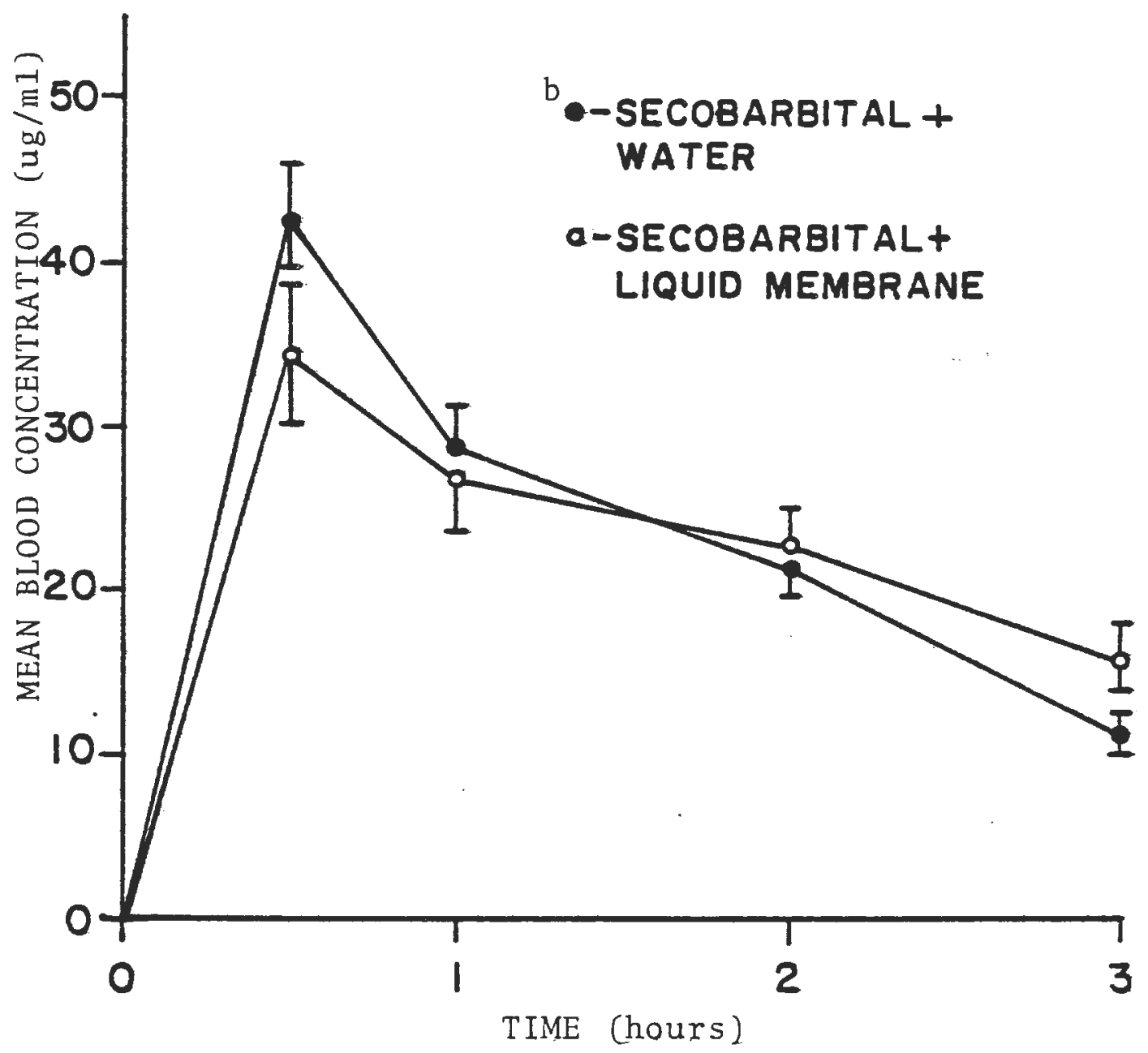

${ }^{a}$ Seconal sodium in water at a dose of $100 \mathrm{mg} / \mathrm{kg}$ was administered by oral intubation; rats received drug plus $4 \mathrm{mls}$ of either liquid membrahe suspension (Code 573-31R) or water.

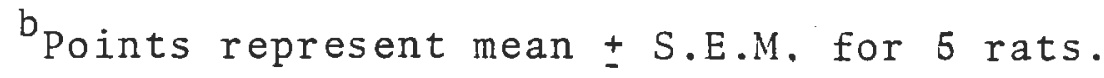




\section{TABLE II I}

Summary of the Effects of Liquid Membrane Administration on Secobarbital Bioavailability Parameters in Ratsa

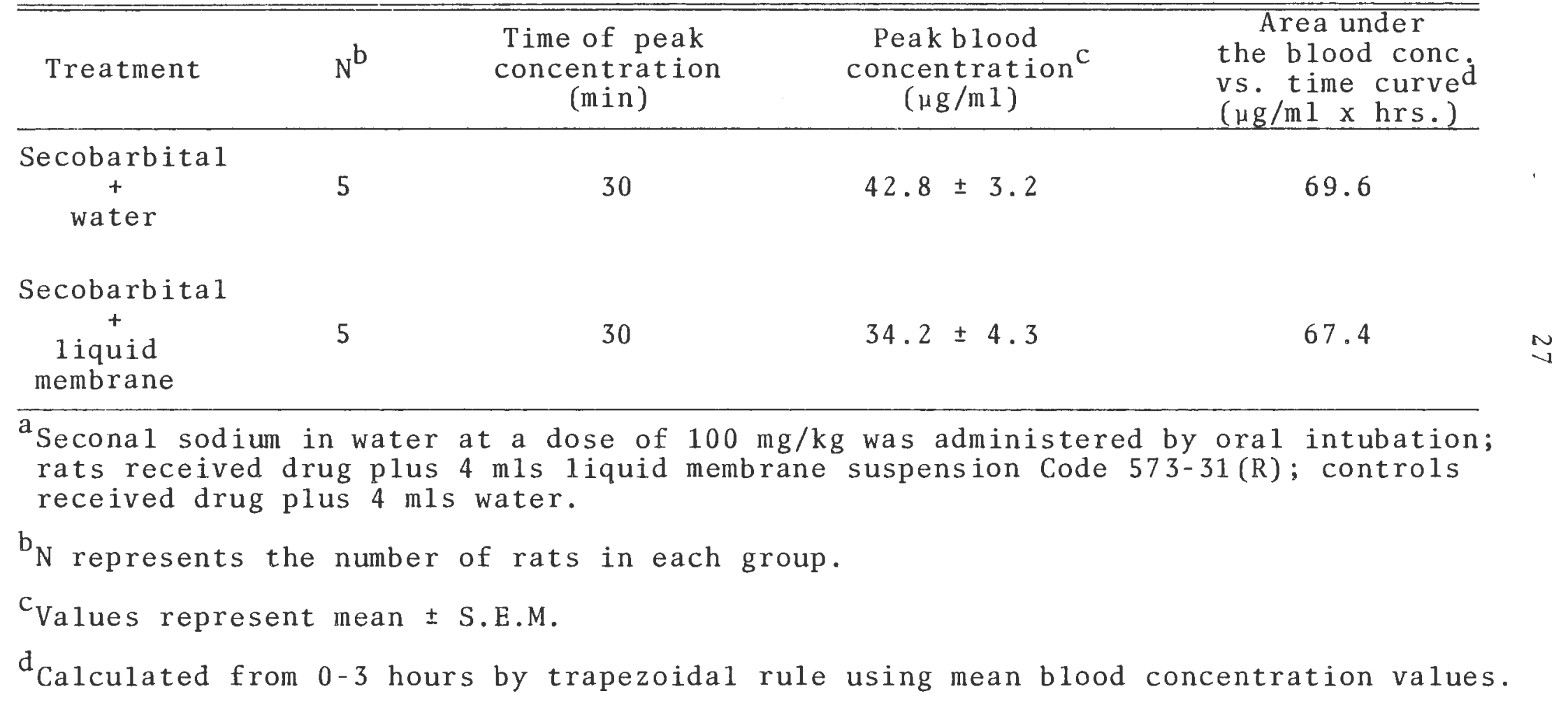




\section{FIGURE II I}

Gas Chromatogram for the Analysis of
Phencyclidine Levels in Rat Blood, $\mathrm{b}$

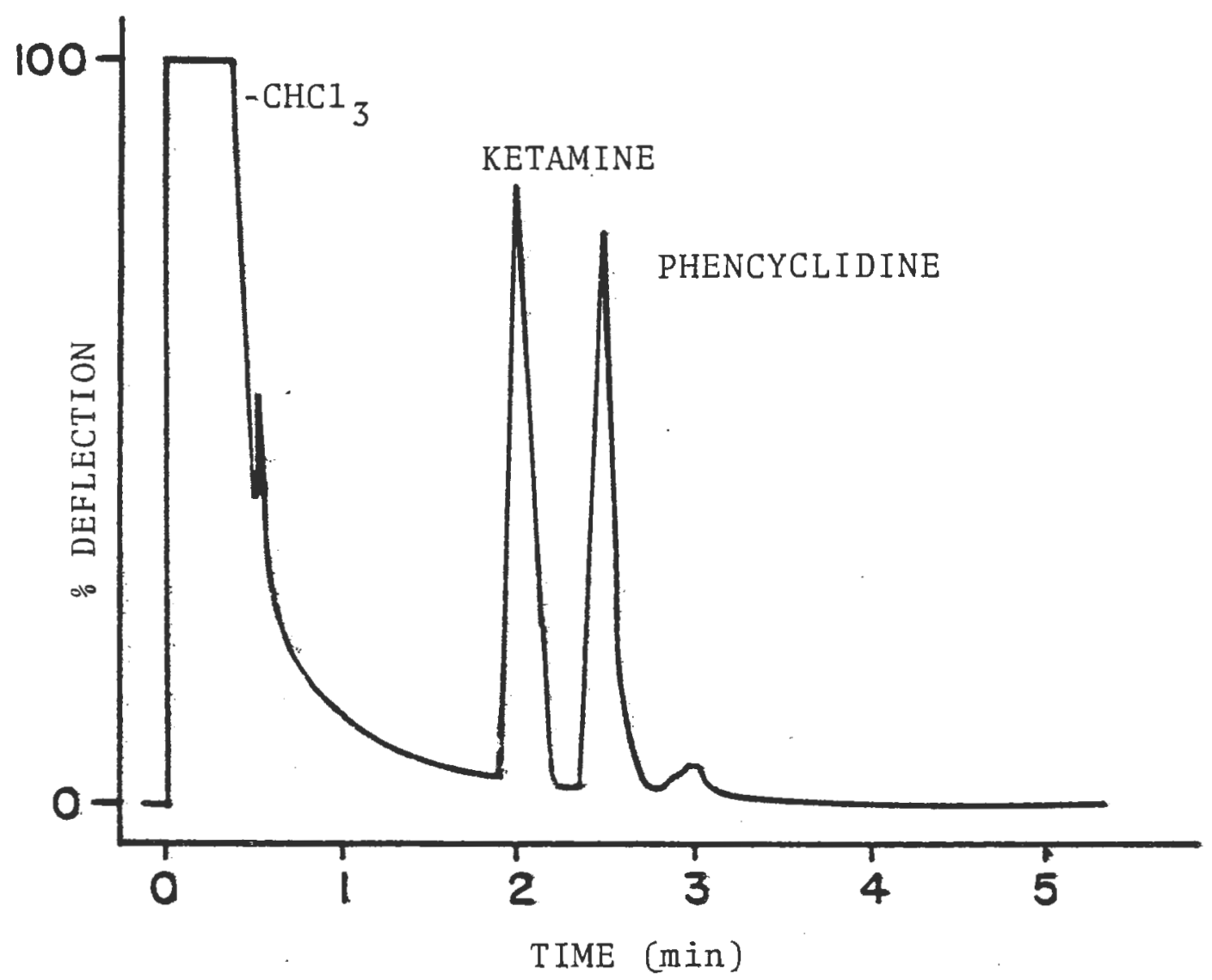

a obtained from the injection of two microliters of a chloroform extract from $0.5 \mathrm{mls}$ whole blood.

${ }^{b}$ Column was a $31 \times 1 / 8 "$ glas column containing $3 \%$ OV-1 on Gas Chrom Q 100/120; Oven temperature-180 . 
FIGURE IV

Effect of Liquid Membrane Administration on Blood Levels of Phencyclidine in Rats

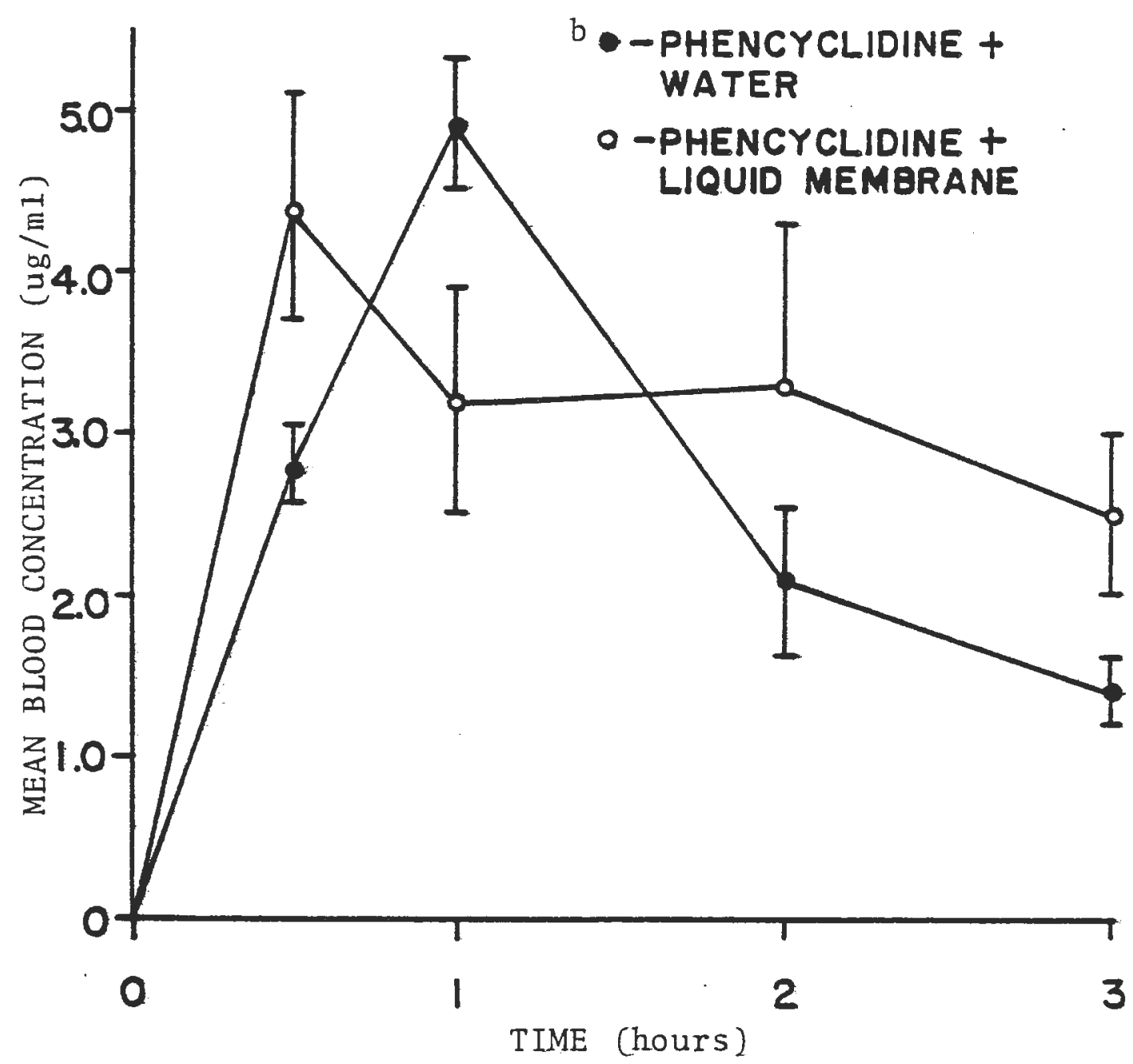

${ }^{a}$ Phencyclidine hydrochloride in water at a dose of $50 \mathrm{mg} / \mathrm{kg}$ was administered by oral intubation; rats received drug plus $4 \mathrm{~m} 1 \mathrm{~s}$ liquid membrane suspension (Code 573-118-2) or water.

${ }^{b}$ Points represent mean $\pm S, E . M$. for 5 rats. 
appeared to peak at one hour after intubation and rapidly declined over the following two hours. The liquid membrane treated group showed peak blood levels of drug at 30 minutes followed by a less rapid decline in levels over the next $2-1 / 2$ hours. No statistically significant differences in blood levels existed owing in part to the exterme variability in the liquid membrane treated group. Area under the curve calculations revealed a $14 \%$ increase in bioavailability of phencyclidine in the liquid membrane treated group (Table IV) .

\section{Recovery of Phencyclidine in Urine}

Analysis of urine revealed the presence of three major metabolites in addition to unchanged phencyclidine (Figure V). Total recovery of phencyclidine over twenty-four hours was calculated by summation of the total amount of metabolites and unchanged drug multiplied by the volume of urine collected for each rat. The mean recoveries for the drug control and liquid membrane treated groups were not significantly different. There appeared to be a slight difference in the distribution of unchanged drug and metabolites within the two groups, with liquid membrane treated group showing a higher mean recovery of unchanged phencyclidine and a lower mean recovery of metabolites as compared to the drug control group. These differences were not statistically significant (Table V). 
TABLE IV

Summary of the Effects of Liquid Membrane Administration on Phencyclidine Bioavailability Parameters in Rats ${ }^{a}$

\begin{tabular}{|c|c|c|c|c|}
\hline Treatment & $N^{b}$ & $\begin{array}{c}\text { Time of peak } \\
\text { concentration } \\
\text { (min) }\end{array}$ & $\begin{array}{l}\text { Peakblood } \\
\text { concentration } \\
(\mu \mathrm{g} / \mathrm{m} 1)\end{array}$ & $\begin{array}{l}\text { Area under } \\
\text { the blood conc } \\
\text { vs. time curved } \\
(\mu \mathrm{g} / \mathrm{m} 1 \text { x hrs })\end{array}$ \\
\hline $\begin{array}{c}\text { Phencyclidine } \\
+ \\
\text { water }\end{array}$ & 5 & 60 & $4.9 \pm 0.40$ & 7.9 \\
\hline $\begin{array}{c}\text { Phencyclidine } \\
+ \\
\text { 1iquid membrane }\end{array}$ & 5 & 30 & $4.4 \pm 0.76$ & 9.2 \\
\hline
\end{tabular}

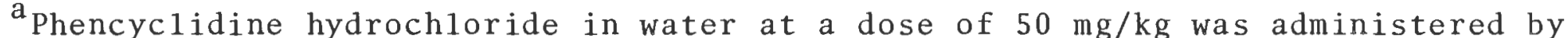 oral intubation; rats received drug plus $4 \mathrm{~m} 1 \mathrm{~s}$ liquid membrane suspension Code 573-118-2; controls received drug plus $4 \mathrm{mls}$ water.

${ }^{\mathrm{b}} \mathrm{N}$ represents the number of rats in each group.

${ }^{\mathrm{C}}$ Values represent mean \pm S.E.M.

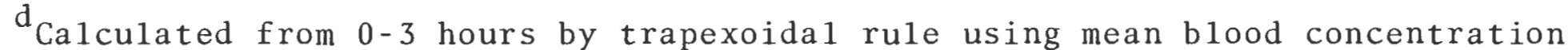
values. 


\section{FIGURE V}

Gas Chromatogram for the Analysis of Phencyclidine and Metabolites
in Rat Urinea,

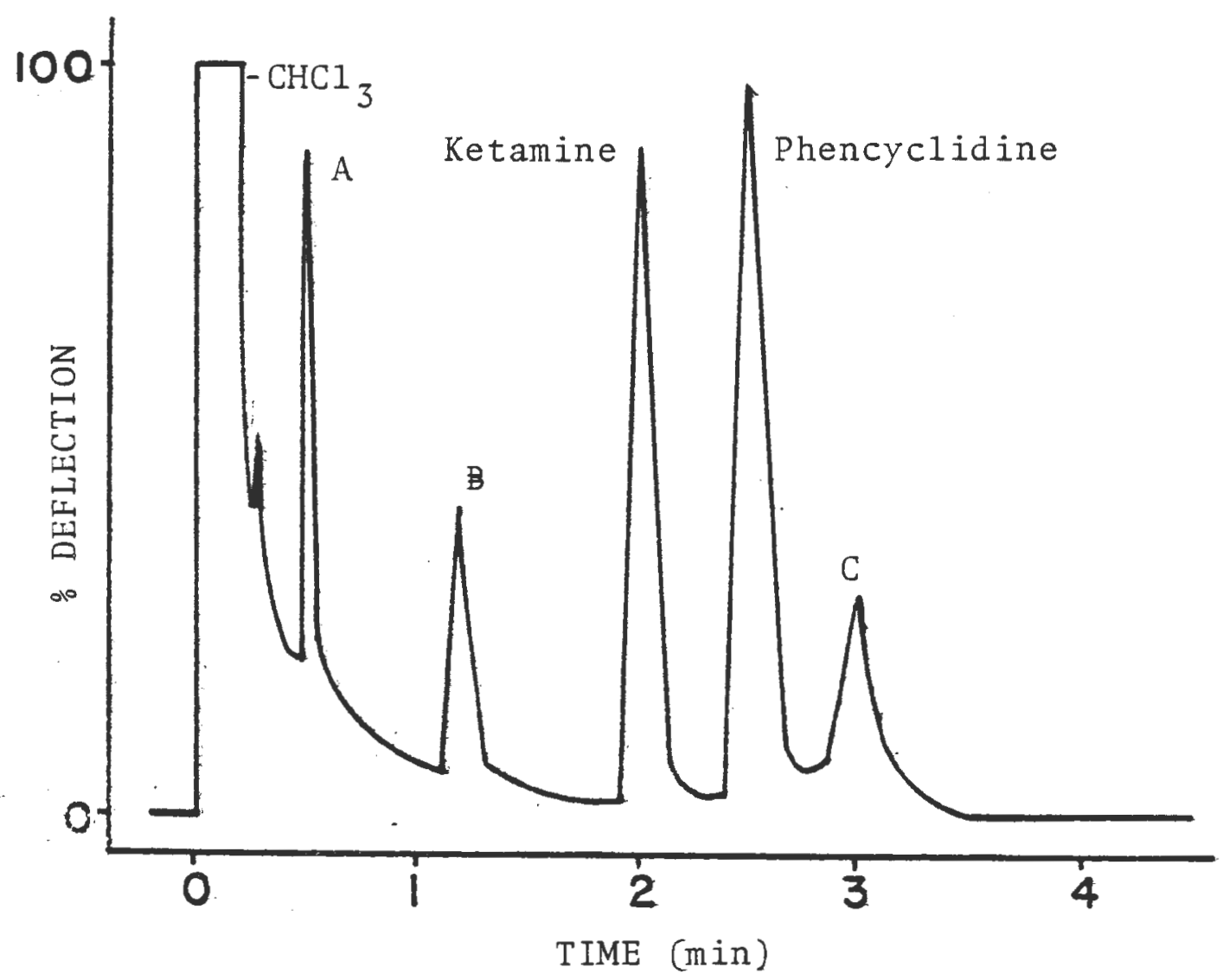

$a_{\text {Obtained from the injection of two microliters of a }}$ chloroform extract from $2 \mathrm{mls}$ urine.

${ }^{b}$ Column was a 3 ' X $1 / 8^{\prime \prime}$ glass column containing $3 \%$ OV-1 on Gas Chrom Q 100/120; Oven temperature-180 .

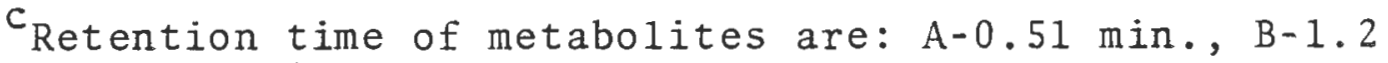
min., $\mathrm{C}-3.0 \mathrm{~min}$. 


\section{TABLE V}

Effect of Liquid Membrane Administration on Recovery of Phencyclidine in Rat Urine ${ }^{a}$

\begin{tabular}{|c|c|c|c|c|}
\hline Treatment & $\mathrm{N}^{\mathrm{b}}$ & $\begin{array}{c}\text { Amount of } \\
\text { unchanged } \\
\text { phencycligine } \\
\text { (mgs) }\end{array}$ & $\begin{array}{c}\text { Amount of } \\
\text { metabolites } \\
\text { (mgs) }\end{array}$ & $\begin{array}{l}\text { Tota } 1 \\
\text { recovery } \\
\quad(\mathrm{mgs}) \mathrm{d}\end{array}$ \\
\hline $\begin{array}{c}\text { Phencyclidine } \\
+ \\
\text { water }\end{array}$ & 5 & $1.06 \pm 0.16$ & $0.61 \pm 0.17$ & $1.67 \pm 0.11$ \\
\hline $\begin{array}{c}\text { Phencyclidine } \\
+ \\
1 \text { iquid membrane }\end{array}$ & 5 & $1.27 \pm 0.20$ & $0.36 \pm 0.05$ & $1.62 \pm 0.21$ \\
\hline
\end{tabular}

a phencyclidine hydrochloride in water at a dose of $25 \mathrm{mg} / \mathrm{kg}$ was administered by oral intubation; rats received drug plus $4 \mathrm{~m} 1 \mathrm{~s}$ 1iquid membrane suspension Code 573-118-2; controls received drug plus 4 m1s water.

$\mathrm{b}_{\mathrm{N}}$ represents the number of rats in each group.

$c_{\text {Total }}$ recovery of phencyclidine and metabolites in urine collected for 24 hours after drug intubation.

$\mathrm{d}_{\text {Values }}$ are mean \pm S.E.M. 
Strychnine Acute Toxicity

Administration of strychnine, at a dose of $25 \mathrm{mg} / \mathrm{kg}$, resulted in $100 \%$ lethality rate in control rats. The mean latency to death was 14.6 minutes. Rats receiving activated charcoal immediately following strychnine intubation remained alive and active with no signs of toxicity. Twentyfour hours after intubations, rats were alive and exhibited no signs of latent toxicity. Rats receiving liquid membrane following strychnine intubation were all dead within 13 minutes with a mean latency of 9.2 minutes (Table VI). 
TABLE VI

Comparison of the Effectiveness of Liquid Membrane and

Activated Charcoal Administration in Preventing Strychnine Toxicity in Ratsa

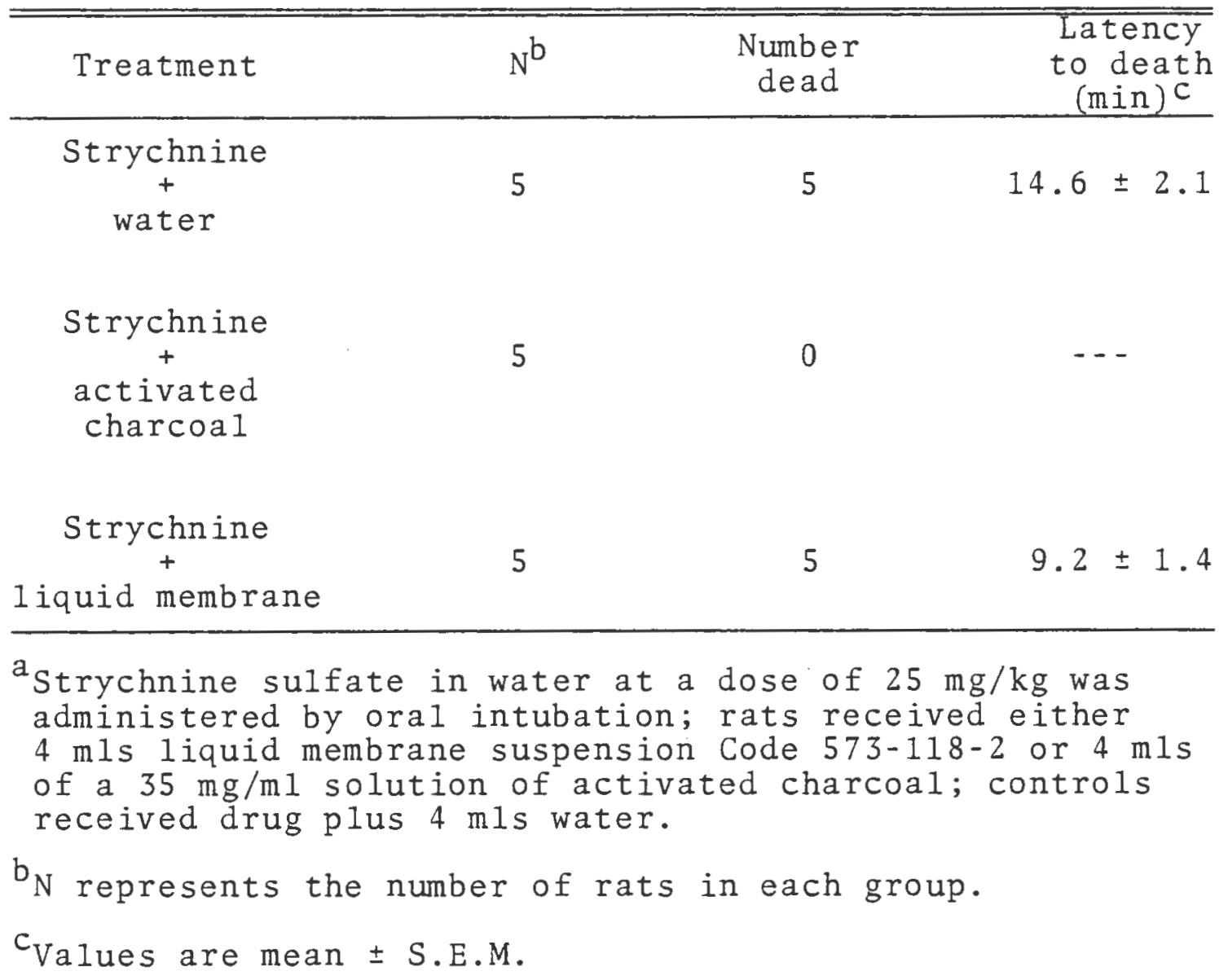




\section{DISCUSSION}

Sleeping time is a frequently employed test for the evaluation of parameters which affect the pharmacological activity of the agent producing the anesthesia. Since the intensity and duration of a pharmacological effect is proportional to the concentration of drug at an effector site, any alterations in the absorption, metabolism or excretion of anesthesia producing drug will alter the duration of action. Many studies have been focused on alterations in sleeping time as a function of biological differences (Quinn et al., 1958) or chemical interactions that affect barbiturate metabolism (Axelrod et a1., 1954). These studies have shown that there is a direct relationship between duration of action (sleeping time) and the plasma and brain tissue levels of drug. Sleeping time experiments have also been extended to studies involving alteration in gastrointestinal absorption of anesthesia producing agents. Recent1y, Picchioni and Consroe (1979) have studied the effect of activated charcoal on phencyclidine toxicity. Their results showed a significant reduction in duration of anesthesia in dogs as a result of activated charcoal treatment. 
Sleeping time experiments in the present study were thus based on the principle that a reduction in the amount of drug available for gastrointestinal absorption due to liquid membrane will result in a concommitant decrease in blood and brain levels of drug and therefore a reduction in the duration of action of the drug.

In both the secobarbital and phencyclidine experiments, there are no differences in the latency to loss of righting response for drug control and liquid membrane treated groups. These data suggest that the rate of absorption from the gastrointestinal tract is not altered by the presence of the liquid membrane and, that the amount of drug available for absorption is sufficient to produce anesthesia. In contrast, liquid membranes do alter sleeping time duration in phencyclidine treated rats. The group receiving liquid membrane showed a $22 \%$ increase in mean sleeping time. These findings suggest that the blood levels of drug necessary to sustain anesthesia are being maintained for a longer period of time in liquid membrane treated animals. This interpretation is supported by blood level experiments.

Although no significant differences exist in mean blood levels between drug control and liquid membrane treated groups over the course of the experiments, a similar trend is apparent in both secobarbital and phencyclidine experiments. Mean peak blood levels in liquid membrane treated groups appear slightly lower than in drug controls, suggesting that a small portion of the original dose may be trapped 
by liquid membranes. However, between the first and second hour after drug intubation there is an apparent leveling in the slope of the elimination portion of the blood concentration versus time curve. This finding tends to correlate well with the effect seen in sleeping time experiments and suggests that although liquid membranes may be trapping small quantities of drug initially, the effect is reversible and the liquid membrane may be serving as a reservoir for sustained release of drug as it passes through the gastrointestinal tract.

This suggestion is supported by comparison of drug bioavailability as measured by area under the blood concentration versus time curve. In the secobarbital experiment, there was less than a $3 \%$ difference in the areas under the curve for drug control and liquid membrane treated animals indicating that the amount of drug absorbed over the three hour sampling period was equal in both groups. In the phencyclidine experiment, the liquid membrane treated group showed a $14 \%$ increase in drug bioavailability over controls. This finding suggests that liquid membrane may enhance the absorption of the basic drug by translocating it further through the intestine to a more favorable alkaline environment.

Total twenty-four hour recovery of phencyclidine in the urine did not differ between drug control and liquid membrane treated groups. This finding further indicates that liquid membrane does not irreversibly trap significant amounts of the original drug dose. 
A comparison of the effectiveness of liquid membrane and activated charcoal for preventing strychnine toxicity revealed that administration of activated charcoal protected all animals against toxicity. This served as a positive contro1. Liquid membrane not only was incapable of preventing toxicity, but appeared to decrease the latency to death when compared to drug controls. This further supports the concept that the liquid membranes may be increasing the rate of translocation of the basic compound, strychnine, into the more alkaline intestinal environment.

The proven efficacy of 1 iquid membranes in vitro does not appear to carry over to the in vivo situation. The inability of liquid membranes to trap and remove drug from the gastrointestinal tract indicates that under physiological conditions, factors exist that may compromise the performance of liquid membranes. Since the principle underlying liquid membrane function requires that the encapsulated aqueous phase remains encapsulated, rupturing of Iiquid membranes would result in leakage of the internal pH sink and a concommitant decrease in the trapping capacity of the system. Rupture occurring after drug has been trapped would result in returning the drug to the external phase (intestinal lumen), making it available once again for absorption.

The leakage effect has been demonstrated in vitro. Chiang et al. (1978) showed that in the presence of bile salts, Iiquid membrane uptake of pentobarbital ceased after ten minutes, followed by increasing drug concentration in 
the donor solution during the next two hours of mixing. Similar results have been shown by Asher and coworkers (1977). In an in vitro system, 1iquid membranes leaked more than $35 \%$ of the encapsulated aqueous phase over a two hour period when contacted with a solution containing bile and pancreatin. These findings indicated that although liquid membranes are composed of non-digestible mineral oils, they are nonetheless subject to the emulsification action of bile salts. The effect of pancreatin on liquid membrane stability has been attributed to the solid content of the crude extract and not the enzymatic activity (Asher et al., 1976).

In addition to the problem of leakage in liquid membranes, another factor governing performance is the maintenance of the dispersion of liquid membrane capsules. suspending techniques are designed to generate many small diameter droplets, hence creating a large external surface area for rapid solute transfer. If the dispersed emulsion droplets coalesce with each other forming new, larger droplets with diameters much over $2 \mathrm{~mm}$, the reduction in surface area becomes limiting for rapid transfer. After oral administration, the minimal agitation occurring in the form of gastrointestinal motility may not be sufficient to maintain the original dispersion for extended periods of time. Asher and coworkers (1976) have shown that in addition to promoting leakage, bile and pancreatin promote extreme and rapid coalescence of liquid membrane droplets in vitro. 
The addition of methylcellulose to the suspending solution appeared to reduce both the amount of leakage and coalescence when liquid membranes were contacted with bile and pancreatin. This phenomenon was attributed to the methylcellulose coating the surface of the droplets and rendering it resistant to bile. Further study indicated, however, that the methylcellulose coating could be competitively replaced by protein such as albumin and that this led to loss of resistance. Another factor which may affect the characteristics of liquid membranes in vivo has been demonstrated by Yang (1979). It was shown that liquid membranes, encapsulating a concentrated pH buffer, are capable of absorbing or losing water when dispersed in solutions hypotonic or hypertonic relative to the internal aqueous phase. This finding implies that variations in osmolality along the gastrointestinal tract may alter the properties of liquid membranes. The effects caused by water absorption or loss have not been studied; however it is likely that this process would not only alter the nature of the internal $\mathrm{pH}$ buffer, but may lead to structural changes compromising liquid membrane stability.

In view of the data, of inadequate liquid membrane stability in in vitro systems simulating physiological conditions of the gastrointestinal tract, the lack of effectiveness of the liquid membrane formulations in the present in vivo study can be attributed to the inability of the membranes to remain in a stable, intact configuration once inside the animal. 
CONCLUSIONS

(1) The liquid membrane formulations used in the present study did not effectively decrease the amount of drug reaching systemic circulation as measured by sleeping time, blood level, urine recovery and acute toxicity experiments. These data confirm previous in vitro findings that a substantial reduction in liquid membrane stability occurs in the presence of gastrointestinal constituents such as bile and pancreatin. The effect of liquid membrane in prolonging the duration of action of phencyclidine, as we 11 as increasing this drug's bioavailability over controls lends support to the potential use of liquid membranes as sustained release devices.

(2) The use of liquid membranes to trap and remove toxins from the gastrointestinal tract has theoretical merit. A more biologically stable liquid membrane formulation, subject to less rupture and coalescence would be necessary for future in vivo testing. 


\section{REFERENCES}

Abdallah, A.H. and Tye, A. A Comparison of the efficacy of emetic drugs and stomach lavage. Amer. J. Dis. Child., 113: $571-575,1967$.

Arena, J.M. Poisoning; toxicology, symptoms, treatments. Edited by I.N. Kugëlmass. 3rd edition. Springfield, IL: Charles C. Thomas, 1974 .

Asher, W.J.; Bovee, K.C.; Hamilton, R.W.; Holtzapple, P.G.; and Vogler, T.C. Liquid membrane capsule system for the treatment of chronic uremia. Artificial KidneyChronic Uremia Program, NIAMDD, NIH, Annual Reports, $1974,1976,1978$.

Asher, W.J.; Vogler, T.C.; Bovee, K.C.; Holtzapple, P.G.; and Hamilton, R.W. Liquid membrane capsules for treatment of uremia. J. Dialysis, 1: 261-284, 1977 .

Asher, W.J.; Bovee, K.C.; Vogler, T.C.; Hamilton, R.W.; and Holtzapple, P.G. Liquid membrane capsules administered to the gastrointestinal tracts of dog for removal of urea from the blood. Clin. Nephrology, 11: 92-96, 1979.

Axe1rod, J.; Reichentha1, j.; and Brodie, B.B. Mechanism of the potentiating action of B-diethylaminoethyl diphenylpropylacetate. J. Pharmacol. Exp. Therap., 112: 49-54, 1954.

Cahn, R.P. and Li, N.N. Separation of phenol from wastewater by the liquid membrane technique. Separation Sci., 9 : 505-519, 1974 .

Chiang, C.W.; Fuller, G.C.; Frankenfeld, J.W.; and Rhodes, C.T. Potential of liquid membranes for drug overdose treatment; in vitro studies. J. Pharm. Sci., 67: 63-66, 1978 .

Chilamkurti, R.N. Studies on the effect of molecular structure of some aromatic compounds on their uptake rates by a liquid membrane system. Unpublished Masters thesis, University of Rhode Island, 1979. 
Chin, L.; Picchioni, A.L.; and Duplisse, B.R. Comparative antidotal effectiveness of activated charcoal, Arizona montmorillonite and evaporated milk. J. Pharm. Sci., 58: $1353-1356,1969$.

Decker, W.J.; Combs, H.F.; and Corby, D.G. Adsorption of drugs and poisons by activated charcoal. Tox. Appl. Pharmaco1., 13: 454-460, 1968.

Dordoni, B.; Willson, R.A.; Thompson, R.P.H.; and Williams, R. Reduction of absorption of paracetamol by activated charcoal and cholestyramine; a possible therapeutic measure. Brit. Med. J., $\underline{3}:$ 86-87, 1973.

Dvorchik, B.H. Microdetermination of blood barbiturates. J. Chromatogr, , 105: 49-56, 1975 .

Fiser, R.H.; Maetz, V.C.; Treuting, J.J.; and Decker, W.J. Activated charcoal in barbiturate and glutethimide poisoning of the dog. J. Pediatr., 78: 1045-1047, 1971.

Frankenfeld, J.W.; Fuller, G.C.; and Rhodes, C.T. Potential use of liquid membranes for emergency treatment of drug overdose. Drug Dev. Comm., 2: 405-419, 1976.

Frankenfeld, J.W. Personal communication, April, 1979.

Goldstein, A.; Aronow, L.; and Kalman, S.M. Principles of Drug Action: The basis of pharmacology. 2nd edition. New York: John Wiley and Sons, 1974.

Gosselin, R.E. and Smith, R.P. Trends in the therapy of acute poisoning. C1in. Pharmacol. Therap., 7: 279-299, 1966.

Hayden, J.W. and Comstock, E.G. Use of activated charcoal in acute poisoning. Clin. Toxicol., $\underline{8}$ : 515-533, 1975.

Holt, L.E. and Holz, P.H. The black bottle. J. Pediatr., 63: $306-314,1963$.

Kitagawa, T.; Nishikawa, Y.; Frankenfeld, J.W.; and Li, N.N. Wastewater treatment by liquid membrane process. Environ. Sci. Technology, 11: 602-605, 1977.

Lawson, A.A.H. and Proudfoot, A.T. Medical management of acute barbiturate poisoning. Acute Barbiturate Poisoning. Edited by $\mathrm{H}$. Matthew. Amsterdam: Excerpta Medica, 1971 .

Levine, R. Pharmacology: Drug Action and Reaction. 2nd edition. Boston: Little, Brown and Company, 1978. 
Levy, G. and Tsuchiya, T. Effects of activated charcoal on aspirin absorption in man. Clin. Pharmacol. Therap., 13: $317-322,1972$.

Li, N.N. U.S. Patent \#3,410,794, Nov. 12, 1968.

Loomis, T.A. Essentials of Toxicology. 3rd edition. Philadelphia: Lea and Febiger, 1978.

Matthew, H.; Mackintosh, T.F.; Tompsett, S.L.; and Cameron, J.C. Gastric aspiration and lavage in acute poisoning. Brit. Med. J., 1: 1333-1337, 1966.

May, S.W. and Li, N.N Enzyme Engineering. Edited by E.K. Pye and L.B. Wingard. New York: Plenum Press, 1974 .

Meyers, F.W.; Jawetz, E.; and Goldfein, A. Management of acute intoxications. Review of Medical Pharmacology. Los Altos: Lange Medical Publications, 1976.

National Clearinghouse for Poison Control Centers. Bulletin, Bethesda, MD, 1978.

Picchioni, A.L.; Chin, L.; Verhulst, H.L.; and Dieterle, B. Activated charcoal vs. "universal antidote" as an antidote for poisons. Tox. App1. Pharmacol., 8: 447$454,1966$.

Picchioni, A.L. and Consroe, P.F. Activated charcoal--a phencyclidine antidote, or hog in dogs. N. Eng. J. Med., 300: 202, 1979 .

Quinn, G.P.; Axelrod, J.; and Brodie, B.B. Species, strain and sex differences in metabolism of hexobarbitone, amidopyrine, antipyrine and aniline. Biochem. Pharmaco1., 1: 152-159, 1958 .

Reynolds, P.C. Clinical and forensic experince with phencyclidine. Clin. Toxico1., 9: 547-552, 1976.

Wallace, H.W.; Stein, T.P.; and Asher, W.J. Evaluation of fluorochemicals for liquid membrane oxygenation. Fed. Proc., 34: 1506-1509, 1975 .

Yang, T.T. Study of the effect of variations of the physica 1 and chemical properties of liquid membrane systems on their ability to function as sinks. Unpublished Masters thesis, University of Rhode Island, 1979. 
APPENDIX 
TABLE A

Some of the Demonstrated Liquid Membrane Systems

\begin{tabular}{|c|c|c|c|}
\hline $\begin{array}{c}\text { Encapsulated } \\
\text { Phase }\end{array}$ & $\begin{array}{c}\text { Liquid Membrane } \\
\text { Phase }\end{array}$ & $\begin{array}{c}\text { Continuous } \\
\text { Phase }\end{array}$ & $\begin{array}{c}\text { Potential } \\
\text { Use }\end{array}$ \\
\hline Aqueous & Oil & Aqueous & $\begin{array}{c}\text { Chronic Uremia/ } \\
\text { Drug Overdose }\end{array}$ \\
Gas & Aqueous & Oil & $\begin{array}{c}\text { Hydrocarbon } \\
\text { Separation }\end{array}$ \\
Fluorocarbon & Aqueous & Blood Oxygenation \\
\hline
\end{tabular}


FIGURE A

Schematic Diagram of Liquid Membrane System for Drug Removal

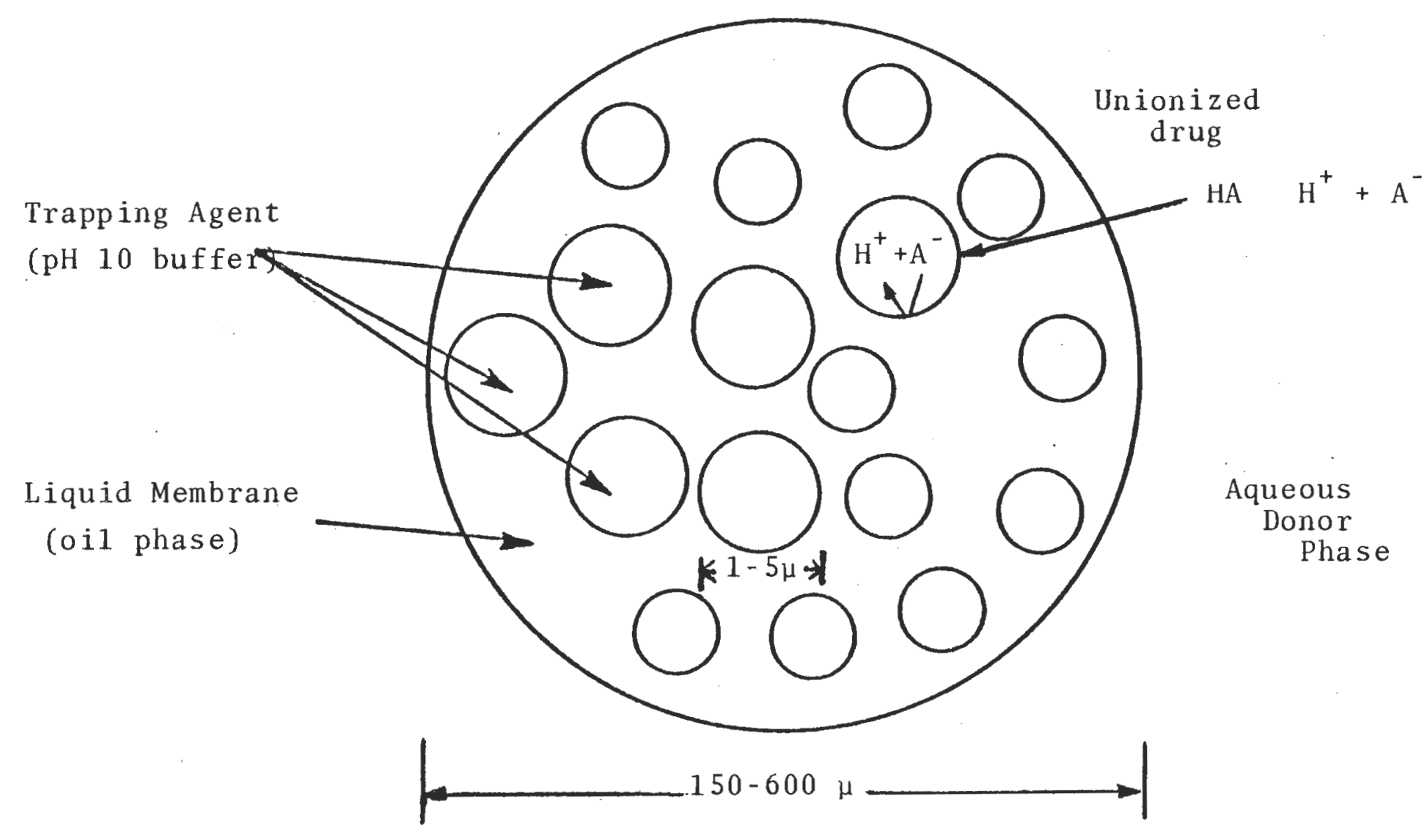


TABLE B

Apparent Partition Coefficients, Dissociation Constants and Transport Constants for Six Barbiturates ${ }^{\mathrm{a}}$

\begin{tabular}{|l|c|c|c|}
\hline & $\begin{array}{c}\text { Dissociation } \\
\text { Constant } \\
\text { (pKa) }\end{array}$ & $\begin{array}{c}\text { Apparent } \\
\text { Partition } \\
\text { Coefficientb }\end{array}$ & $\begin{array}{c}\text { Transport } \\
\text { Rate Constant } \\
\text { (min-1) }\end{array}$ \\
\hline Barbital & 7.86 & 0.00 & 0.037 \\
Phenobarbita1 & 7.37 & 0.21 & 0.116 \\
Butabarbita1 & 8.01 & 0.07 & 0.188 \\
Pentobarbita1 & 8.03 & 0.50 & 0.401 \\
Amobarbita1 & 7.87 & 0.36 & 0.662 \\
Secobarbita1 & 7.90 & 0.83 & 0.727 \\
\hline
\end{tabular}

${ }^{a}$ From Chiang et a1. (1978).

bobtained from equilibrium partitioning experiments of the drugs between liquid membranes with no internal trapping agents and the aqueous donor phase.

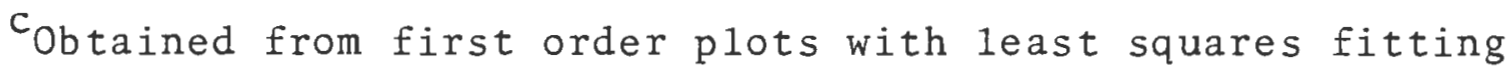
program. 


\section{VITA}

Alan P. Agins was born on October 8, 1951 in New Rochelle, N.Y. Mr. Agins received his Bachelor of Science degree (Magna Cum Laude) in Psychology at the State University of New York at Brockport in 1973.

In $1977, \mathrm{Mr}$ Agins began his graduate education at the University of Rhode Island in the Department of Pharmacology and Toxicology and completed the requirements for the Master of Science degree in May 1980.

During his graduate education, Mr. Agins received Teaching and Research Assistantships from the Department of Pharmacology and became a member of the Rho Chi Society.

- Mr. Agins will continue his graduate education as a Ph.D candidate in the Department of Pharmacology and Toxicology. His research will be conducted in abstentia at the Special Pharmacological Animal Laboratory of the Food and Drug Administration in Maryland. 